\title{
SISTEM KEPERCAYAAN SEBAGAI BASIS-STRUKTUR SOSIAL MASYARAKAT NELAYAN LIUKANG TUPABBIRING DI KABUPATEN PANGKEP
}

\section{The Belief System as the Basic Social Structure of the Fishermen Society in Liukang Tupabbiring of Pangkep Regency}

Oleh: Ibrahim*

*Dosen Fakultas Ilmu Sosial Universitas Negeri Makassar Alamat: Kampus IJNM Fakultas Ilmu Sosial JL. A.P. Pettarani Ibrahimfgivahoo.co.id

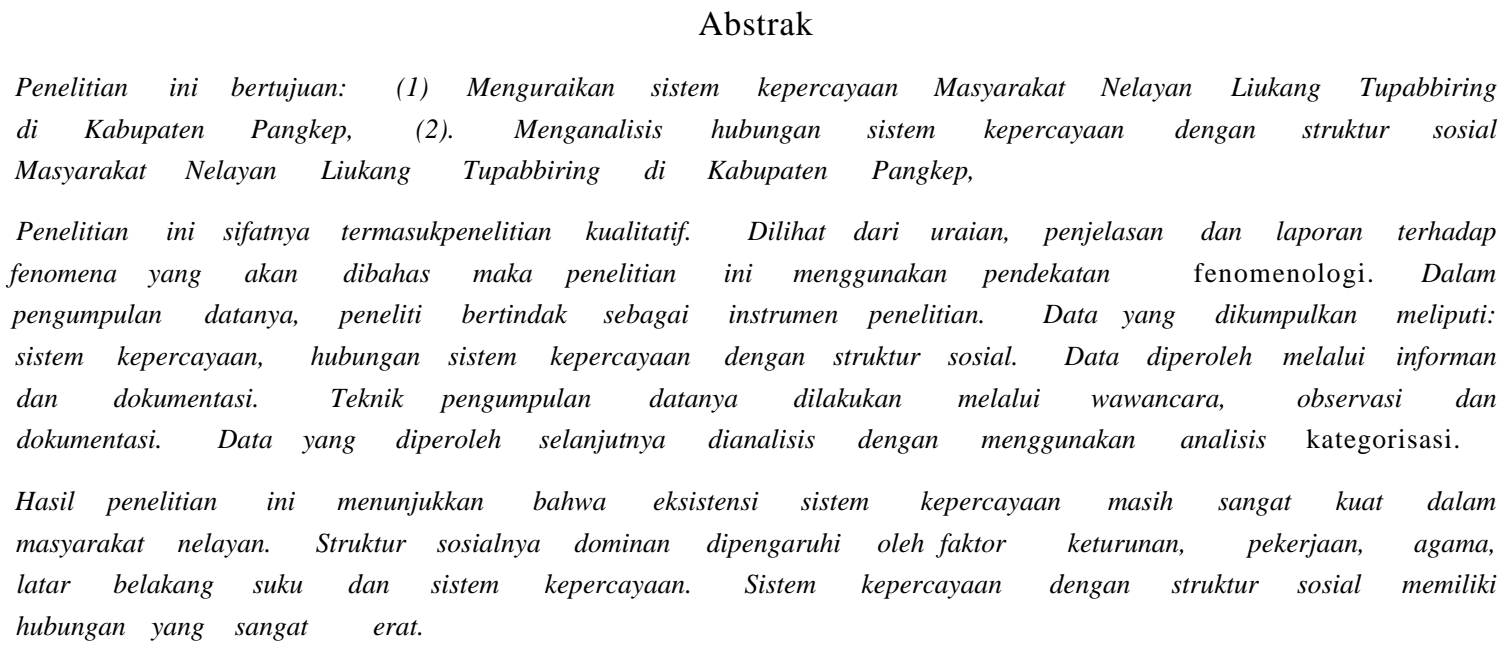

Abstrack

\begin{abstract}
This research aims: (I) to explain the belief system of the fishermen society in Liukang Tupabbiring of Pangkep regency, (2) to analyze the relationship between the belief system and the social structure of the fishermen society in Liukang Tupabbiring of Pangkep regency.

From the characteristic, this research is categorized as a qualitative research. However, from the statement, explanation and report to the phenomena which will be discussed in this research using phenomenology approach. In collecting data, the researcher acts as the research instrument. The data collecting included: the belief system, and the relationship between the beliefsystem and social structure. The data collected through informan and documentation. The data collecting technique done by interview, observation and documentation. Then, the data analyzed by using categorization analysis.

The result of this research shows that the existence of the belief system still so strong in the fishermen society. Its social structure mainly influenced by genetic system, occupation, religion, ethnic background, and beliefsystem. The belief system and social structure has a great correlation.
\end{abstract}

\section{LATAR BELAKANG}

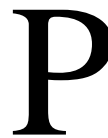

embangunan selama ini sudah gencar dilakukan oleh pemerintah namun ternyata kehidupan masyarakat nelayan di pulau-pulau kecil, terpencil dan terisolasi masih jauh dari kemajuan. Masyarakat nelayan di pulau-pulau kecil mcrupakan komunitas sosial yang identik dengan berbagai macam pemaknaan miring dipandang dari morfologis sistem kehidupannya. Masyarakat terkebelakang, masyarakat pinggiran, masyarakat primitif dan masyarakat miskin merupakan identitas yang masih melekat pada kehidupan masyarakat nelayan. Selanjutnya, pembicaraan kehidupan masyarakat nelayan tidak pernah sunyi dan ketinggalan dibahas, dikaji, diseminarkan namun kenyataannya belum banyak merubah kenyataan kondisi dari kehidupan mereka. 
Bahkan masyarakat nelayan dari sisi kemajuan ilmu pengetahuan dan teknologi, sistem kepercayaan dan upacara ritual, kadang diidentikkan pula dengan "sisasisa keprimitifan".

Pada tahap selanjutnya, antara perkembangan kehidupan agama dan kepercayaan pada suatu masyarakat dipengaruhi oleh perkembangan peradaban masyarakat tersebut. Sementara pada sisi lain, kepercayaan-kepercayaan yang dianut, tumbuh dan berkembang pada suatu masyarakat dan tidak mustahil memiliki implikasi terhadap perkembangan dan kemajuan masyarakat tersebut. Pada masyarakat primitif atau sederhana, terdapat kesesuaian antara tingkat kehidupan keagamaan dan kepercayaan dengan peradabannya. Selain itu, sistem kepercayaan pada masyarakat tertentu juga mustahil tidak memiliki implikasi terhadap struktur sosial masyarakatnya.

Perasaan kagum terhadap objek-objek sakral yang tetap dilestarikan oleh para nelayan merupakan perasaan yang nyata, bukan sekedar memberikan sifat sakral kepada benda-benda tersebut tetapi juga wujud khayal ini berada dalam pikiran para nelayan maksudnya bahwa benda-benda atau wujud-wujud yang dipercayai oleh nelayan sesungguhnya dapat mempengaruhi tingkah laku mereka.

Kluckhohn dalam bukunya Nahavo Witchraft, menunjukkan bagaimana ilmu sihir dikaitkan dengan tekanan-tekanan yang hampir tidak tertahan dalam kehidupan sosial dan psikologi, yang disebabkan oleh kehidupan keluarga yang sangat terisolasi dalam masyarakat pengembala domba yang terpencar-pencar. Kebudayaan Nahavo melarang segala bentuk pernyataan permusuhan secara terbuka diantara anggota-anggota keluarganya, meskipun di dalam penelitian tersebut diperoleh fakta bahwa dalam kehidupan mereka mendorong timbulnya banyak perasaan ambivalensi dan permusuhan. Akibatnya, rasa benci dan permusuhan tersebut mereka tahan dan tidak dilampiaskan karena hal ini merupakan hal yang mereka percayai sebagai hal yang tabu dalam kehidupannya. Lebih lanjut dengan kondisi dilema itu mengakibatkan kepercayaan kepada wanita-wanita penyihir yangjahat memberi peluang kepada orang Nahavo untuk melampiaskan kebencian yang ditahannya dilampiaskan dengan menggunakan "jasa sihir" atau "magi hitam" dalam menuntut balas terhadap musuh-musuh mereka, baik yang nyata maupun yang tidak.

Penggunaan "jasa sihir" pada kebudayaan Nahavo menunjukkan bahwa kepercayaan kepada wanita-wanita penyihir merupakan wujud dari komitmen mereka untuk mempertahankan hubungan atau jaringan sosial dalam kehidupan masyarakatnya. Ada pesan dalam kepercayaan mereka dimana hubungan dan semangat mempertahankan solidaritas merupakan hal yang mereka percayai sebagai norma dan sekaligus nilai yang harus ditaati dan dipertahankan.

Pada masyarakat Manu yang mendiami Kepulauan Bismarck, ada kepercayaan diantara orang-orang Manu terhadap roh-roh orang bara mati. Bagi mereka, orang-orang yang baru saja meninggal diyakini/ dipercayai masih secara aktif berada di desa orangorang yang masih hidup, yang berfungsi sebagai sejenis polisi susila, atau penjaga tatakrama di desa tersebut. Olehnya itu, roh-roh tersebut dalam kedudukannya seperti ini terhadap orang-orang di desa itu selalu waspada memperhatikan agar kewajiban-kewajiban keuangan dan larangan-larangan seksual, yang merupakan hal-hal pokok dalam sistem sosial orang Manu, senantiasa dipatuhi dan dijalankan secara sempurna. ${ }^{2}$

Sementara itu, kepercayaan suku Bali, dunia ruh berada dipuncak suatu gunung tinggi, yaitu Gunung Agung. Suku-suku bangsa yang menghuni pulau-pulau dan tinggal di tepi laut, sebaliknya percaya bahwa tempat ruh berada di seberang laut, di suatu pulau lain. Orang Yamdena, penduduk Pulau Tanimbar, percaya bahwa nitu pergi ke dunia ruh di seberang laut, di atas suatu batu karang yang tinggi sebelah baratdaya, yaitu di Pulau Selu. Kepercayaan bahwa ruh menghuni tempatnya di dunia akhirat dianut banyak relegi suku bangsa di Indonesia. Karena hampir semua suku bangsa di Indonesia telah menganut salah satu agama besar, kepercayaan itu sekarang berangsurangsur digantikan oleh keyakinan bahwa roh orang yang meninggal pada akhirnya akan ditempatkan di surga atau di neraka. ${ }^{3}$

Masyarakat Liukang Tupabbiring sebagai suatu komunitas nelayan jika dibandingkan dengan perkembangan dan kemajuan yang telah dialami pada

Kluckhohn, C, 1944. Nahavo Witchcraf, Cambridge, Massachusetts: Peabody Muesum, h. 54-55

Fortune, R.F The Sorcerers of Dobu. London: Routledge and Sons, h.49

Koentjaraningrat. 1987. Sejarah Antropologi I. Jakarta: Pn. UI Press, h. 208 
masyarakat daratan di Kabupaten Pangkep masih jauh tertinggal. Kehidupan masyarakat nelayan di pulaupulau kecil Liukang Tupabbiring di Pangkep memiliki karakteristik yang tampak dengan jelas. Pulau-pulau kecil pesisir Pangkep tersebut, tergolong sebagai wilayah kecamatan yang dikategorikan sebagai daerah kantong-kantong kemiskinan. Hal ini disebabkan; (1) faktor Kalitas Sumber Daya Manusia (SDM) yang masih rendah, (2) faktor Keterjangkauan transfortasi dan komunikasi yang masih terbatas, (3) faktor pemasaran hasil-hasil tangkapan nelayan yang sangat jauh, (4) faktor keterbatasan institusi/lembaga untuk permodalan sangat terbatas, (5) faktor teknologi mata pencaharian hidup sebagai nelayan belum maksimal dan (6) beberapa faktor lainnya.

Keyakinan agama, kepercayaan dan struktur sosial masyarakat nelayan Liukang Tupabbiring tumbuh dan berkembang secara bersama dalam kehidupan mereka. Masyarakat nelayan selalu berhadapan dengan situasi yang tidak menentu terutama ketika melaut mencari nafkah sehingga sistem kepercayaan tetap eksis dalam kehidupannya meskipun rhereka sadari hal tersebut bertentangan dengan keyakinan agama mereka. Kondisi inilah yang menjadi faktor yang menentukan bagi keberlangsungan dan bahkan eksistensi struktur masyarakat nelayan. Oleh karena itu, penelitian ini penting untuk mengkaji: Bagaimana sistem kepercayaan Masyarakat Nelayan Liukang Tupabbiring dan Bagaimana hubungannya dengan struktur sosial Masyarakat Nelayan Liukang Tupabbiring di Kabupaten Pangkep.

Tujuan penelitian, untuk menguraikan sistem kepercayaan Masyarakat Nelayan Liukang Tupabbiring di Kabupaten Pangkep dan menganalisi hubungan sistem kepercayaan dengan struktur sosial Masyarakat Nelayan Liukang Tupabbiring di Kabupaten Pangkep. Manfaat penelitian ini merupakan informasi berharga bagi berlangsungnya transformasi-transformasi dalam sistem Kepercayaan dan struktur Masyarakat Nelayan Liukang Tupabbiring khususnya dan masyarakat nelayan pada umumnya. Bahan-bahan pertimbangan, pedoman dan pendukung bagi usaha-usaha pembinaan, pemberdayaan dan pembangunan kearah kesejahteraan kehidupan Masyarakat Nelayan Liukang Tupabbiring. Khasanah tentang pengkajian sistem kepercayaan dan struktur sosial masyarakat dan menjadi salah satu upaya bagi pembangunan dan pengembangan budayanasional. Hasil penelitian inijugamenjadi literatur rujukan bagi peneliti dan pemerintah setempat untuk mengadakan studi lebih lanjut.
Penelitian ini sifatnya termasuk penelitian kualitatif. Dilihat dari uraian, penjelasan dan laporan terhadap fenomena yang akan dibahas maka penelitian ini menggunakan pendekatan fenomenologi. Dalam pengumpulan datanya, peneliti bertindak sebagai instrumen penelitian. Data yang dikumpulkan meliputi: sistem kepercayaan, hubungan sistem kepercayaan dengan struktur sosial. Data diperoleh melalui informan dan dokumentasi. Teknik pengumpulan datanya dilakukan melalui wawancara, observasi dan dokumentasi. Data yang diperoleh selanjutnyadianalisis dengan menggunakan analisis kategorisasi.

\section{KAJIAN PUSTAKA}

\section{Konsep Sistem Kepercayaan}

Agama sebagai suatu sistem keyakinan, berisikan ajaran dan petunjuk bagi para penganutnya supaya selamat (dari api neraka) dalam kehidupan setelah mati. Agama dapat juga didefinisikan sebagai suatu sistem keyakinan yang dianut dan tindakan-tindakan yang diwujudkan oleh suatu kelompok atau masyarakat dal menginterpretasikan dan memberi respon terhadap apa yang dirasakan dan diyakini sebagai yang gaib dan suci. Sebagai suatu sistem keyakinan, agama berbeda dengan sistem-sistem keyakinan atau ismeisme lainnya karena landasan keyakinan keagamaan adalah pada konsep suci (secred) yang dibedakan dari, atau dipertentangkan dengan, yang duniawi (profari), dan pada yang gaib atau supranatural (supernatural) yang menjadi lawan hukum-hukum alamiah (natural). Salah satu ciri yang mencolok dari agama adalah penyerahan diri secara total kepada Tuhannya.

Sesuatu yang sakral lebih mudah dikenali dari pada didefinisikan. Sesuatu yang dianggap sakral adalah sesuatu yang memiliki misteri dengan tingkatan standar kekaguman maupun dengan standar ketakutan yang melekat pada aspek materi dari sesuatu yang disakralkan. Jika didalami akan sesuatu yang dianggap sakral, sebenarnya intinya ada pada kepercayaan yang melekat pada diri seseorang, artinya bukan sesuatu atau benda tersebut yang merupakan tanda dari yang sakral, akan tetapi sebenarnya adalah aneka macam sikap dan perasaan dari seseorang itu sendiri yang sebenarnya menjadi penguat sehingga sesuatu hal dapat menjadi sakral dalam pandangan seseorang atau masyarakat.

Weber dalam bukunya The Sociology of Religion secara tegas mengemukakan bahwa ragam konsekuensi makna pada seni magis atau yang sakral, 
muncul dari berkembangnya dunia roh-roh, setan-setan dan tuhan-tuhan. Makhluk-makhluk ini tidak dapat dikuasai atau dipahami dalam arti konkrit, tetapi mereka mewujudkan satu bentuk makhluk transcendental yang biasanya hanya dapat dicapai melalui mediasi simbolsimbol daji arti-arti, yang selanjutnya diwakili sebagai bayangan dan tidak riil. Karenanya di balik bendabenda riil dan kejadian-kejadian riil hanya merupakan gejala-gejala atau simbol-simbol. ${ }^{4}$

Sementara itu, Taylordalam bukunya The Primitif Culture, menjelaskan secara sistematis bagaimana suatu agama atau kepercayaan mengalami evolusi. Evolusi paling dasar, ketika manusia percaya bahwa makhluk-makhluk halus itulah yang menempati alam sekeliling tempat tinggal manusia, karena mereka bertubuh halus, manusia tidak dapat menangkap dengan panca inderanya. Makhluk halus itu mampu berbuat berbagai hal yang tidak dapat diperbuat oleh manusia. Berdasarkan kepercayaan semacam itu, makhluk halus menjadi objek penghormatan dan penyembahan manusia dengan berbagai upacara keagamaan berupa do'a, sesajen, atau korban. Kepercayaan seperti inilah oleh Taylor disebut Animisme.

Tingakat selanjutnya dari evolusi agama, ketika manusia mulai percaya bahwa gerak alam ini dimotori atau digerakkan oleh sesuatu kekuatan atau jiwa yang berada di belakang peristiwa dan gejala alam itu. Sungai-sungai yang mengalir, gunung yang meletus, angin topan yang menderu, matahari, bulan dan tumbuh-tumbuhan, semuanya bergerak karena jiwa alam ini. Kemudian jiwa alam ini dipersonifikasikan, dianggap sebagai makhluk-makhluk yang berpribadi yang mempunyai kemauan dan pikiran. Makhluk halus yang ada dibalik gerak alam seperti itu disebut dewadewa alam. Tingkat kedua dari evolusi agama dan kepercayaan ini disebut polytheisme. Tingkatan ini adalah kelanjutan dari pemujaan roh nenek moyang.

Tingkat terakhir dari evolusi agama atau kepercayaan, dimulai dari evolusi agama yang bersamaan dengan timbulnya susunan kenegaraan di dalam masyarakat manusia. Menurut Taylor, ketika muncul susunan kenegaraan di masyarakat, timbul juga kepercayaan bahwa di alam dewa-dewa juga terdapat susunan kenegaraan yang serupa dengan susunan kenegaraan manusia. Pada kehidupan masyarakat, para dewa yang tertinggi yaitu raja dewa, para menteri sampai pada dewa yang paling rendah. Susunan masyarakat dewa semacam itu kemudian berevolusi dan akhirnya menimbulkan kesadaran baru bahwa sebenarnya semua dewa pada hakikatnya penjelmaan dari satu dewa yang tertinggi itu. Akibat dari kepercayaan itu, berkembanglah kepercayaan kepada satu Tuhan yaitu Tuhan Yang Maha Esa dari sinilah timbul berbagai agama bertuhan satu atau monotheisme.

\section{Konsep Struktur Sosial}

Konsep sosiologi tentang struktur sosial sering digunakan untuk menjelaskan tentang keteraturan sosial, yaitu menunjuk pada prinsip perilaku yang berulang-ulang dengan bentuk dan cara yang sama. Secara sosiometris kadang-kadang dapat diartikan sebagai konsep psikologis dari hubungan-hubungan sejumlah anggota dalam kelompok kecil. Dalam hal ini, struktur sosial diartikan sebagai hubungan timbal balik antara posisi-posisi sosial dan antara perananperanan.

Struktur sosial dan sistem sosial merupakan dua konsep dalam lapangan sosiologi dimana kedua hal ini ketika diarahkan kepada perbincangan masalah konsep masyarakat maka dua konsep tersebut merupakan suatu kesatuan yang sangat erat. Struktur sosial dipandang dari dimensinya sesungguhnya merupakan bagian integral dari suatu sistem sosial. Untuk menghindari pemahaman diantara keduanya maka dikemukakan ciri-ciri struktur sosial sebagai berikut: (1). Struktur sosial mengacu pada hubungan-hubungan sosial yang pokok yang dapat memberikan bentuk dasar pada masyarakat: memberikan batas-batas pada aksi-aksi yang kemungkinan besar dilakukan secara organisatoris, (2). Struktur sosial mencakup semua hubungan sosial antara individu-individu pada saat tertentu. Oleh karena itu, struktur sosial dapat disebut sebagai aspek non proses dari sistem sosial yang pada intinya adalah situasi statis dari sistem sosial, (3). Struktur sosial merupakan seluruh kebudayaan masyarakat yang dapat dilihat dari sudut pandangan teoritis. Artinya dalam setiap meneliti tentang kebudayaan selayaknya diarahkan pada pemikiran terhadap pelbagai derajat susunan sosialnya. 4). Struktur sosial merupakan realitas sosial yang bersifat

\footnotetext{
4 Weber. 1958. The Protestant Ethic and The Spirit of Capitalism. New York, Scribners.

s Taylor. 1971. The Primitif Culture, Englewood Cliffs, N.J: Prentice-Hall. h. 87

- Kahmad, Dadang 2000. Sosiologi Agama. Bandung: Rosda Karya., h. 16

Soekanto, Soerjorio, 1983.Pribadi dan Masyarakat. Bandung: Alumni., h. 30
} 
statis atau kenyataan yang membeku, sehingga dapat dilihat kerangka tatanan dari berbagai bagian tubuhnya yang berbentuk struktur. Jadi struktur sosial adalah aspek statis dari suatu proses atau fungsionalisasi dari sistem sosial, (5). Struktur merupakan tahapan perubahan dan perkembangan masyarakat yang mengandung dua pengertian, yaitu pertama, di dalam struktur sosial terdapat peranan yang bersifat empiris dalam proses perubahan dan perkembangan, kedua, dalam setiap perubahan dan perkembangan tersebut terdapat tahap perhentian stabilitas, keteraturan dan integritas sosial yang berkesinambungan sebelum kemudian terancam proses ketidakpuasan dalam tubuh masyarakat.

Marx mengemukakan suatu pernyataan yang tegas bahwa masyarakat bukanlah penjumlahan individu-individu tetapi terwujud melalui totalitas hubungan dan situasi dimana individu saling berhadapan. Pernyataan Marx ini dapat dipahami bahwa individu sebagai aktor dalam kehidupan masyarakat selalu dalam keadaan atau kondisi dinamis. Hal ini disebabkan setiap aktor tidak dapat melepaskan diri dari keterlibatan dengan aktor lainnya. Dengan kata lain, individu dalam suatu masyarakat sebagai suatu kesatuan sosial yang dibentuk pondasi utamanya adalah adanyajaringan atau hubungan (struktur sosial). ${ }^{8}$

Dewasa ini, pengaruh kesadaran kolektif atas individu berkurang dalam masyarakat pluralitas. Jika semua orang menjadi sama dan diikat oleh solidaritas mekanis, maka setiap tindakan yang menyimpang dari pola umum akan menimbulkan reaksi negatif masyarakat. Orang tidak senang melihat bahwa diantara mereka ada yang hendak memamerkan posisi. Lebih-lebih setiap pelanggaran hukum langsung dirasa oleh masyarakat sebagai ancaman terhadap eksistensinya, dan dibalas dengan hukuman berat.

\section{PEMBAHASAN}

\section{Sistem Kepercayaan Masyarakat Nelayan Liukang Tupabbiring}

Beberapa tempat yang dianggap masyarakat nelayan Liukang Tupabbiring yang dipercayai sebagai akkarama antara lain:

\section{a). Masjid sebagai tampa akkarama}

Kesakralan atau kekeramatan Masjid Nurul Ulama yang terdapat di Pulau Salemo dihubungkan dengan keramatnya orang yang membangunnya. Masyarakat nelayan khususnya di Pulau Salemo, masih mempercayai bahwa barakka (keramat) dari beberapa ulama yang membangun masjid tersebut masih ada melekat pada masjid tersebut. Suasana magis yang mengalami kehidupan para ulama yang pernah hidup di Pulau Salemo masih terpelihara dan melekat pada masjid yang ditinggalkannya. Lebih lanjut, Hasanuddin, S.Ag. MA mengemukakan, "Jam dinding di salah satu masjid Nurul Ulama masih merupakan jam dinding peninggalan para ulama dahulu. Begitu pula beduk serta papan nama yang bertuliskan ukiran timbul berbahasa arab di masjid ini masih merupakan hasil peninggalan para ulama Salemo."

Benda-benda peninggalan para ulama Salemo masih dirawat dan dijaga kelestariannya oleh masyarakat nelayan khususnya di Pulau Salemo. Benda-benda peninggalan tersebut selalu dibersihkan setiap saat supaya tidak cepat lapuk. Pembersihan benda-benda tersebut dilakukan olehjamaah masjid ini dengan bersama-sama yang disertai kehati-hatian. Maksud dari pembersihan secara berjamaah agar barakka yang melekat pada benda-benda peninggalan tersebut dapat diperoleh dengan berjamaah pula. Demikianlah perlakuan dan kepercayaan nelayan terhadap eksistensi Masjid Nurul Ulama yang disakralkan.

\section{b). Kuburan sebagai tampa' karama'}

Salah satu makam yang dipercayai oleh Masyarakat nelayan memiliki keramat (akkaramaki) yaitu makam yang terdapat di Pulau Balang Caddi. Penuturan Imam Desa Balang Caddi tentang keberadaan makam tersebut;

Kuburu karamakkanga itimborang
kanna nasaba riolonjo mae nia
anrampei angkanayya nia serre bakke manyu
ri tamparan nasaba lammasa anjo bakkea
abballang-ballangi nampa ri kallonna
ammake bilang-bilang. Anjo bakkea ni sorongi
untuk ni pammanyu ri tau jaiya assulu
ritamparang tetapi anjo bakkea sorei pole ri
Pulo Balang Caddi. Pissiapai ni pamanyu
tetapi nia tonji pole sengke nai ri puloa.
Iaminjo na allemo tau jaiya na awangga ri
pakkuburanga itimborang. Saggenna kamma-

\footnotetext{
" Marx, K. 1964. Selected Writing $m$ sociology and Social Philosopy. New York: McGraw-Hill. h. 57

'Soekanto, Soerjono, 1982. Teori Sosiologi Tentang Pribadi Dalam Masyarakat. Jakarta: Ghalia Indonesia, h. 32

${ }^{10}$ Wawancara, dengan Hasanuddin, S.Ag. MA, di Pulau Salemo.
} 
kamma anne tena tau sere anggusseng anrupai anjo bakkea. Lanri kammanami anjo napercayai mi tau jaiya angkanayya anjo bakkea teai bakke tau samara tetapi bakke akkarama."

(Kuburan yang keramat yang terdapat di selatan pulau keberadaannya berasal dari cerita turun temurun sejak dahulu dimana ada informasi bahwa mayat yang hanyut dimana seluruh tubuhnya berbelang-belang namun tidak mengalami kerusakan dan di lehernya bergantung tasbih. Pada saat mayat tersebut diketemukan oleh warga, mayat tersebut dihanyutkan ke laut dengan alasan bahwa mayat tersebut tidak ada yang kenal dan lagi pula ada ketakutan warga jangan sampai arwah orang hanyut tersebut dapat menakut-nakuti warga pulau. Namun ada keanehan yang diperlihatkan oleh mayat tersebut setiap kali dihanyutkan ke laut akan tetapi mayat tersebut tetap saja singgah sandar di pulau ini. Hal ini lakukan berkali-kali namun kejadiannya masih seperti itu. Akhirnya warga mempercayai bahwa keberadaan mayat yang tidak dikenal ini bukan orang biasa dan sengaja datang untuk membawa barakka bagi warga pulau ini. Akhirnya oleh warga, mayat tersebut kemudian dikuburkan di selatan pulau dan kuburannya bias kita saksikan sekarang).

Kedatangan masyarakat nelayan ke makam keramat tersebut berbeda-beda tujuan. Ada yang datang minta do'a keselamatan karena akan melakukan ibadah ke tanah suci (haji). Ada nelayan yang datang karena ingin mengekspresikan tanda kesyukuran karena telah mendapatkan dalle (reski) yang banyak. Adajuga sekeluarga datang ke makam tersebut untuk mendapatkan barakka agar supaya pemuda atau anak gadisnya cepat mendapatkan jodoh. Kedatangan keluarga dengan maksud supaya anaknya cepat dapat jodoh biasanya dilakukan dengan mengikat tali atau daun pandang ke tiang atau nisan atau bagian lain di sekitar makam keramat tersebut. Pada saat akan mengikat sesuatu mereka berdo'a sambil berjanji kelak kalau permohonannya untuk cepat ketemu jodohnya mereka akan datang kembali untuk membuka ikatan tersebut yang disimbolkan dengan melepaskan salah satu ekor binatang (ayam atau kambing). Ada juga nelayan datang ketika akan melakukan perjalanan jauh untuk melaut mencari rezeki. Sebelum kepergiannya biasanya mereka datang ke makam tersebut untuk supaya mendapatkan berkah keselamatan selama keperginnya dan pulang dengan selamat membawa hasil yang banyak. Itulah pemandangan yang setiap saat bisa disaksikan di makam keramat di Pulau Balang Caddi.

\section{c). Toddoka sebagai tampa' karama'}

Todokka merupakan salah satu tempat yang sangat dikeramatkan oleh nelayan. Tempat ini terletak agak dekat pesisir perbatasan Kabupaten Maros dengan Kabupaten Pangkep. Toddoka yang dikenal nelayan, posisinya di Muara Sungai Binanga sangkara yaitu suatu sungai yang menjadi tapal batas antara Kabupaten Pangkep dengan Kabupaten Maros. Deskripsi toddoka dapat dikemukakan sebagai kumpulan tiang kayu hitam (benteng kaju sappu). Jumlah tiang kaju sappu yang dapat kita lihat sampai saat ini sekitar ribuan batang yang ditancapkan maupun yang sudah rebah ke dasar laut. Nelayan yang datang untuk appadongko di Toddoka karena adanya ikatan secara leluhur artinya kehidupan orang tua mereka secara turun temurun selalu datang untuk appakalompo sehingga mereka merasa tidak nyaman dari tradisi itu ketika tidak ke sana. Ada nelayan datang ziarah karena merasa lebih aman dan ada perasaan lega dalam melaksanakan aktivitas. Ada juga melakukan ziarah disebabkan oleh rasa syukur atas apayang telah dialami oleh nelayan.

Persembahan benteng oleh nelayan kepada roh/ penunggu Toddoka didasarkan pada informasi tradisi lisan secara turun temurun. Hal ini dituturkan sejarah singkat keberadaan Toddoka oleh salah seorang pemerhati budaya, H. Muh. Arif sebagai berikut:

Kerajaan siang sebelum masuknya Islam
menganut agama Kristen. Ibodo Banda adalah
raja terakhir yang berkuasa ketika kerajaan
siang masih memeluk Agama Kristen. Pada
masa pemerintahan Ibodo Banda, ada rom-
bongan dagang dari Gresik yang berlabu di
Pela-buhan Binanga Sangkara. Tujuan utama
kedatangan rombongan dagang dari Gresik
adalah untuk menjajaki hubungan dagang
dengan Kerajaan Siang. Anak Koda Bonang
sebagai pemimpin rombongan dagang Gresik
lalu memilih pandang laut sebagai tempat
tinggal sementara. Selama menjajaki hu-
bungan dagang dengan Kerajaan Siang


rombongan dagang Gresik mengadakan pengajian yaitu memperkenalkan atau menyebarkan Agama Islam kepada penduduk kampung Pandang Laut. Ibodo Banda yang menjadi pemimpin kerajaan pada saat itu merasa tidak senang oleh karena bertentangan dengan keyakinannya. Ibodo Banda kemudian mengusir rombongan dagang Gresik dari kampung Pandang Laut. Pada saat akan meningalkan Kampung Pandang Laut yang disaksikan oleh Ibodo Banda. Anak Koda Bonang, sebagai pimpinan rombongan tersebut menancapkan batang bambu (Toddo) pas di muara sungai Binanga Sangkara kemudian berkata: ini adalah tanda bahwa saya akan datang kembali untuk mengIslamkan Kerajaan Siang. Rombongan dagang Gresik tersebut kemudian menuju ke kerajaan Gowa dan Tallo lalu mengadakan perjanjian yang bunyinya: Rua karaeng serre ata, Karaeng Gowa ajjari Somba Opu (Sombayya ri Gowa) dan Tallo sebagai pemangku adat (Mangkubumi). Salah satu isi perjanjian itu adalah tidak boleh mengadakan perang sebelum ada persetujuan dari Sombayya di Gowa dan Mangkubumi Tallo. Setelah Islam berkembang di kerajaan Gowa dan Tallo maka diseranglah Kerajaan Siang untuk di-Islamkan. Setelah kerajaan siang jatuh, Kerajaan Gowa membentuk perwakilan yang disebut "Jannang Gowa " yang dijabat oleh Karaeng Allu. Karaeng Allu ketika akan pergi untuk membantu Gowa memerangi Belanda, Karaeng Allu menancapkan Toddo (batang bambu yang digunakan oleh setiap anak buah kapal untuk mengayuh atau mendorong kapal/perahu) sambil berkata; Manna mabella lampangku, liu bate onjokko kumammoterang empoa ri paddaserangku. Kunjung kuboli nyawaku, kupadongko tallasakku, kupattantuang kalengku tamammaliang $^{\prime \prime 2}$

\section{d). Pulau sebagai tampa' karama'}

Terlepas dari kepercayaan nelayan terhadap Pulau Camba-Cambang sebagai pulau yang akkarama, juga masyarakat nelayan mengibaratkan pulau ini sebagai surga. Nelayan menjadikan pulau ini salah satu tempat sentral pelaksanaan tradisi jene-jene sappara" tiap tahun. Bahkan ada kepercayaan dikalangan nelayan pulau ini sebagai pulau keramat untuk mendapatkan keselamatan, rezeki dan jodoh. Akibatnya setiap tahun yaitu pada saat upacara tradisional "jene-jene sappara" tepatnya setiap hari rabu di Bulan Syafar selama satu bulan selalu dipenuhi atau dipadati pengunjung. Bahkan menurut pengamatan peneliti seandainya semua pengunjung yang datang yang masih ada di atas perahu masingmasing naik di pulau itu maka kapasitas pulau itu tidak akan menampung orang yang datang mengikuti tradisi "jene-jene sappara".

\section{Kepercayaan yang Berhubungan dengan Pekerjaan Nelayan}

Pada saat pertama kali akan mengoperasikan perahu/kapal (ammungasa), nelayan memiliki beberapa kepercayaan. Tidak dimulai pada hari naas, hari jumat dan tidak pada saat ada orang meninggal di pulaunya karena nelayan mempercayai permulaan tahun yaitu perhitungan kalender Qamariah 1 Muharram tiap tahun adalah hari panas. Nelayan mempercayai memulai pengoperasi pertama perahu/ kapal baru dalam tiga keadaan waktu tersebut akan berakibat seperti: selalu mengalami masalah, tidak akan berberkah hasil yang diperoleh, pemilik dan sawi akan sakit-sakitan, selalu tangkapan sedikit dan kadang pada saat mengoperasikannya menimbulkan korban jiwa. Selain itu, pada saat akan mengoperasikan perahu/ kapal baik punggawa (juragan), sawi maupun keluarga mereka tidak boleh mengatakan tena (de 'gaga) mereka mengganti kata tersebut untuk maksud sesuatu yang tidak ada dengan mengatakan towai (Makassar) atau masempo (Bugis).

Seorang nelayan yang akan melaut dan mendapatkan informasi bahwa di pulau di mana ia tinggal, j ika ada orang yang sedang mau membuat saj ian kaddo minnyak maka nelayan tersebut akan menunda kepergiannya. Jika memang tetap harus melakukan perjalanan namun belum dibaca/masak kaddok minyyaknya maka nelayan tersebut datang ke rumah orang yang sedang membuat kaddok minnyak untuk meminta dibungkuskan ramuan kaddok minnyak untuk di bawah serta pada saat melaut meskipun hanya sedikit. Bagi nelayan hal ini adalah do'a dan keselamatan selama dalam perjalanan. Nelayan Liukang Tupabbiring mempercayai bahwa kaddok minnyakyang belum dibaca baru melakukan perjalanan

${ }^{12}$ Wawancara, dengan H. Muh. Arif. Hari sabtu, tanggal 22 maret 2008, tempat MTs/MA Darussalam Anrong Appaka. 
pada hal mereka ketahui maka biasanya akan mengalami kecelakaan atau kehilangan sesuatu dalam perjalanannya.

Pada saat melakukan aktivitasnya di tengah laut, nelayan Liukang Tupabbiring juga memiliki beberapa kepercayaan. Pada saat akan melaut tidak boleh melangkahi alat-alat penangkapan yang akan digunakan, tidak boleh mengucapkan kata tidak ada (towai) masempo) tetapi sebaliknya jika mengucapkan katakata porno maka akan mendapat hasil tangkapan yang banyak. Nelayan tidak boleh mengucapkan kata atau kalimat yang berhubungan dengan binatang yang memiliki empat kaki misalnya; kerbau, kuda, kucing dan dilarang menyebut nama hewan yang sejenis kera. Hal ini dipercayai bahwa, pertama; hasil penangkapan sedikit atau bahkan sama sekali tidak ada diperoleh, kedua; akan mengalami kekurangan atau kehilangan sesuatu, dan ketiga; perjalanan akan mengalami malapetaka misalnya sakit, kecelakaan dan bahkan kematian.

Masyarakat nelayan pada saat melakukan perjalanan di tengah laut, baik menggunakan sampang (lopi) maupun kapal (biseang) sangat santun terhadap semua tempat. Ketika sementara dalam perjalanan meninggalkan suatu pulau menuju suatu pulau, menuju suatu gusung, ketika perahu/kapal mengarah atau membelakangi gundukan batu karang dan hal-hal yang berhubungan dengan suatu tempat di laut maka kesantunan dan penghormatan nelayan terhadap tempat-tempat itu tarhpak dari perilaku mereka. Nelayan ketika menunjuk tempat-tempat seperti yang telah disebutkan sebelumnya jari telunjuknya dibengkokkan, tidak akan meludah atau membuang suatu kotoran, haluan kapal tidak secara langsung diarahkan ke arah tempat-tempat tersebut dan tidak akan banyak mengungkapkan cerita atau riwayat suatu tempat secara panjang lebar ketika sementara dalam perjalanan menggunakan perahu/kapal.

\section{Kepercayaan Yang Berhubungan Dengan Waktu (Hari-Hari)}

Salah satu pedoman hari-hari baik yang masih digunakan oleh nelayan untuk melakukan aktivitas kesehariannya adalah perhitungan pokok tahun menurut Agama Islam yaitu 1 Muharram dalam delapan tahun yang disebut satu pariama sebagai berikut:

1. Kalau pokok tahun $\mathrm{j}$ atuh pada hari selasa disebut tahun I (Alif)

2. Kalau pokok tahun jatuh pada hari sabtu disebut tahun $£(\mathrm{Ha})$
3. Kalau pokok tahun jatuh pada hari kamis disebut tahun $£($ Kha')

4. Kalau pokok tahun $\mathrm{j}$ atuh pada hari sabtu disebut tahun $\wedge$ (Dal depan)

5. Kalau pokok tahu jatuh pada hari rabu disebut tahun i_i (Ba)

6. Kalau pokok tahu jatuh pada hari ahad disebut tahun j (Wa) ,

7. Kalau pokok tahu jatuh pada hari jumat disebut tahun $\mathbf{J}>$ (Dal Akhir)

8. Kalau pokok tahu jatuh pada hari senin disebut tahun $j(\mathrm{Za})$

Kedelapan permulaan Bulan Muharram tersebut, oleh masyarakat nelayan dianggap oleh mereka sebagai nakasa taun. Implementasi nakasa taun dalam masyarakat nelayan dapat disaksikan ketika akan melakukan aktivitas. Umumnya nelayan berusaha untuk mencari tahu hari dan tanggal berapa nakasa taun tersebut. Jika masyarakat nelayan sudah mengetahui maka hampir dipastikan bahwa mereka selalu untuk menghindari hari dan tanggal tersebut. Namun demikian jika hari dan tanggal jatuhnya nakasa taun tersaebut tidak dapat dihindari maka masyarakat nelayan biasanya melakukan appisabbi terlebih dahulu. Hal ini dilakukan oleh mereka untuk menghindarkan diri dari kejadiankejadian yang tidak diinginkan seperti; kecelakaan, kehilangan, sakit dan lain-lain.

Jika Hari Ahad naga menghadap ke Utara

Jika Hari Senin naga menghadap ke Timur

Jika Hari Selasa naga menghadap ke Selatan, Timur dan Tenggara

Jika Hari Rabu naga menghadap ke Barat Laut

Jika Hari Kamis naga menghadap ke Utara

Jika Hari Jumat naga menghadap ke Selatan Barat/Barat Daya

Jika Hari Sabtu naga menghadap ke Selatan Barat/ Barat Daya

Petunjuk hari-hari dengan Naga ini dalam masyarakat nelayan masih ada yang menggunakannya. Jadi untuk memulai aktivitas melaut, menanam padi atau melakukan apa saja hendaknya selalu dihindari atau menghindari mulut naga atau tidak berhadapan dengan naga agar aktivitas melaut mendatangkan hasil yang banyak juga tanaman padi terhindar dari serangan hama dan penyakit atau bencana-bencana lainnya (menghindar sengatan naga). 
Kegiatan keagamaan dan upacara-upacara di sekitar lingkaran kehidupan nelayan misalnya; perkawinan, kelahiran, masuk/naik rumah baru, merupakan norma-norma yang mengandung nilai yang sangat dalam dan kompleks. Kedalaman nilai dan kompleksitasnya hanya nelayan yang dapat mengurai secara panjang lebar. Namun yang tampak dalam hidup dan kehidupan keseharian nelayan adalah gambaran kehidupan yang bersahaja. Kehidupan bersahaja yang tampak muncul dari kondisi alam dan perpaduan dengan kepercayaan yang tumbuh bersama lingkungan sosial nelayan. Kesederhanaan, keterbatasan, kekurangan, kemiskinan menjadi hal yang biasa dalam kehidupan mereka. Satu yang masih bersama dalam kehidupan nelayan tidak mau disebut miskin akan tetapi budaya dan sikap tolong menolong di kalangan nelayan merupakan warisan leluhur melalui penanaman nilai-nilai agama dan budaya yang sampai saat ini masih kuat di kalangan. Hal ini senada dengan apa yang dikemukakan oleh Drs. Jumain:

Kontribusi nilai budaya khususnya sistem kepercayaan terhadap eksistensi struktur sosial nelayan secara horizontal, selain mengukuhkan persatuan dan kesatuan, integrasi sosial terbangun, solidaritas sosial tumbuh, semangat menolong masih terpelihara dan gotong royong masih kuat juga memberikan implikasi terhadap beberapa bidang dalam kehidupan nelayan Liukang Tupabbiring secara umum. ${ }^{13}$

Aspek pengendalian sosial, sistem kepercayaan merupakan pondasi/dasar yang paling fundamental bagi eksistensi struktur sosial masyarakat nelayan. Sub-sub struktur yang eksis di kalangan nelayan dipengaruhi oleh temperatur kepercayaan nelayan terhadap obyek-objek kepercayaan mereka sebagai nelayan. Sikap untuk tidak meremehkan kemampuan orang lain atau memandang rendah orang lain tumbuh dari kesadaran kepercayaan ketika pengalaman leluhur mereka yang kedatangan Nabi Khaidir kemudian dia hinakan sehingga lahir kutukan tidak akan tumbuh kelapa di Pulau Karangrang nampaknya menjadi peringatan bagi masyarakat nelayan untuk selalu hormat kepada siapapun baik kepada sesama masyarakat nelayan itu sendiri maupun kepada siapapun yang datang kepulaunya.

Kuatnya kesadaran terhadap kepercayaan mereka juga berdampak kepada harmonisasi struktur masyarakat nelayan Liukang Tupabbiring. Hal ini dibangun dari proses secara alamiah di kalangan nelayan diantaranya melalui beberapa hukum adat; bagi warga pulau yang membuat aib di pulaunya maka ia akan diusir, olehnya itu dalam kehidupan masyarakat nelayan jarang sekali terjadi pelecehan seksual terhadap perempuan. Siapapun yang berbuat aib di pulau di samping mereka akan diusir juga keluarga mereka akan dikucilkan atau dicemooh oleh masyarakat pulau. Bahkan menurut H. Muh. Arif;

Anjo mange riolo punna nia tau aggau appasirisiri ri serrea pulo iyareka appangaddi ni gaukangi hukuman adaka "paopangi butta iyareka poeng nilabui". Siagang risesena tau niaka silariang nihukungi angkanayya anne tau silarianga nikana matemi na tenamo naakulle anggonjoki pulona."-

(Dahulu kalau ada penduduk pulau yang melakukan kegiatan yang memalukan misalnya memperkosa atau kumpul kebo (hubungan di luar nikah) diadakan hukuman adat yang disebut "paopangi butta atau nilabu" begitu pula bagi penduduk yang silariang maka hukuman yang pantas bagi mereka adalah sudah dianggap tiada atau sudah mati dan kedatangannya kembali kepulau sudah tidak diterima)."

Pelaksanaan musyawah terhadap sesuatu masalah di antara nelayan dengan melibatkan keterwakilan sub-sub struktur masyarakat merupakan bentuk kesadaran kolektif bermusyawarah. Kesadaran tersebut sedikit banyaknya dipengaruhi oleh kesadaran kolektif yang dibangun secara alamiah dalam hubungan dan interaksi dalam setiap upacara-upacara ritual, keagamaan di kalangan mereka. Salah satu ritual tahunan yang berkaitan dengan lahirnya nilai kesadaran kolektif nelayan dalam segala aspek kehidupan khususnya dalam bermusyawarah adalah jene-jene sappara. Pelaksanaan ritual ini tiap tahun oleh nelayan tidak ada kepanitiaan secara khusus melainkan semua masyarakat nelayan dengan kesadarannya masingmasing terlibat secara spontanitas tanpa diarahkan, tanpa diorganisasi, tanpa dimotivasi. Bukan hanya ritual jene-jene sappara sebagai salah satu sumber lahirnya kesadaran kolektif nelayan namun Hal-hal lain dari setiap bangunan sistem kepercayaan secara umum berpengaruh terhadap fungsi dan peran dalam struktur yang ada dalam masyarakat nelayan.

" Wawancara, dengan Drs. Jumain hari Rabu,tanggal 22 Agustus 2007, di Pulau Balang Lompo.

${ }^{14}$ Wawancara, dengan H. Muh. Arif, Hari Sabtu, tanggal 22 M et 2008, Tempat MTs/MA Darussalam Anrong Appaka. 
Sementara itu, pengendalian sosial yang nyata dan tegas pada masyarakat nelayan menyebabkan tatanan kehidupan di kalangan mereka menjadi terjaga dan harmonis. Buktinya pada kehidupan bermasyarakat di pulau sampai saat ini masih berlangsung kebiasaan untuk tidak mengunci pintu-pintu rumah mereka pada saat akan bepergian. Mereka hanya memberitahukan kepada tetangga atau keluarga dekat bahwa dia akan pergi. Penyampaian tersebut sudah dimaknai oleh tetangga mereka sebagai amanah untuk melihat, mengawasi dan menjaga rumah mereka.

Kelompok-kelompok atau lembaga-lembaga yang tumbuh dalam kehidupan masyarakat nelayan sebagai pencerminan sistem kepercayaan yang mereka tumbuhkembangkan justru menjadi hal yang sangat komplementer dalam keberlangsurigan kehidupan mereka di pulau-pulau kecil. Kelompok-kelompok atau lembaga-lembaga yang ada misalnya kelompokkelompok yang didasarkan kepada jenis aktivis nelayan dan lembaga-lembaga misalnya lembaga adat, lembaga pendidikan, lembaga atau institusi keagamaan eksistensi semua kelompok dan lembaga/institusi tersebut berhubungan secara timbal balik dengan eksistensi status dan fungsinya meneguhkan sistem kepercayaan dan struktur masyarakat nelayan sampai saat ini.

Keterkaitan sistem kepercayaan dengan struktur masyarakat nelayan menunjukkan keterkaitan yang erat. Perpaduan antara semangat yang terbangun dari kepercayaan terhadap obyek-obyek kepercayaan, pelaksanaan ritual dan upacara-upacara yang berkaitan dengan siklus kehidupan dan keyakinan keagamaan masyarakat nelayan menjadi nilai-nilai dasar dan sekaligus menjadi acuan dalam pola interaksi secara personal maupun secara kolektif/kelompok dengan kelompok yang berdampak kepada adanya pemahaman terhadap peran dan status masing-masing. Akibatnya resistensi konflik di kalangan kelompok-kelompok nelayan relatif rendah.

Hal lain, integrasi sosial tumbuh tanpa paksaan (coersion) dan saling ketergantungan di dalam bidang ekonomi. Sementara itu, struktur sosial secara horizontal pada masyarakat nelayan tidak relevan manakala dikaitkan dengan pernyataan bahwa integrasi sosial di kalangan nelayan terbangun relatif karena paksaan (coercion). Integrasi sosial pada masyarakat nelayan terbangun karena dua pondasi dasar. Pertama, wujud kebersamaan dibangun di atas kedekatan keturunan dan kekerabatan di antara masyarakat nelayan. Umumnya nelayan yang berdomisili di pulau- pulau sebagai suatu keluarga besar. Keberadaannya sekarang tidak lepas dari kesesuaian atau ada hubungan keluarga ketika dihubungankan dengan leluhur mereka yang pertama kali datang ke pulau yang ditempatinya. Olehnya itu, konteks integrasi sosial nelayan lebih dekat kepada kedekatan keluarga dan kekerabatan. Hal ini jika dihubungkan dengan solidaritas Durkheim maka termasuk dengan solidaritas organik.

Pondasi dasar kedua terbangunnya integrasi sosial nelayan adalah karena keniscayaan geografis. Tidak bisa disangkal oleh nelayan bahwa hidup dan kehidupan mereka sangat tergantung kepada ketersediaan sumberdaya alam di laut. Profesi penduduk Liukang Tupabbiring dapat dikatakan $99 \%$ beraktivitas sebagai nelayan selebihnya melakukan usaha/profesi PNS dan berdagang namun sesungguhnya aktivis usaha yang dilakukannya juga bersentuhan dengan kebutuhan hidup nelayan dan bahkan PNS yang ada di pulau tidak sedikit juga rangkap profesi untuk melaut di luar waktu dinas untuk menambah keuangan keluarga apalagi pada musim-musim ikan dan cumi-cumi. Dua pondasi dasar terbangunnya integrasi sosial nelayan yang telah dikemukan sekaligus meneguhkan bahwa dengan kedua pondasi itu pulalah yangmenumbuhkembangkan saling ketergantungan ekonomi. Atas dasar ini struktur sosial secara horizontal dalam kehidupan nelayan meskipun dominannya kelompok di kalangan mereka namun karena dibentengi dengan sistem kepercayaan yang sama maka semakin meneguhkan masyarakat nelayan sebagai masyarakat yang bersahaja dengan kadar integrasi sosial yang tumbuh karena kedekatan dan saling ketergantungan dalam kehidupannya. Dengan demikian, integrasi sosial yang terbangun di antara mereka disebut Integrasi Sosial Organikmekanik.

Hal lain yang dapat menunjukkan keterkaitan sistem kepercayaan dengan struktur sosial nelayan adalah ketika bersentuhan dengan kehidupan keagamaan sebagai muslim ternyata di kalangan mereka para tokoh agama dalam hal ini; ustas, muballig, guru agama, imam masjid (kampung), guru mengaji, guru barazanji dan imam desa menempati status terhormat dalam bidang sosial keagamaan. Faktor yang menunjukkan kondisi ini terjadi adalah menyangkut wawasan, kemampuan, pengetahuan dan keterampilan yang mereka miliki. Secara alamiah siapapun nelayan yang memiliki kemampuan, pengetahuan, wawasan dan keterampilan dalam hal keagamaan (Islam) maka meskipun ia bukan keturunan bangsawan, dan suku apapun (Bugis atau Makassar), profesi apa pun bahkan 
sawi sekalipun misalnya, akan mendapatkan status yang terhormat dalam acara-acara yang berkaitan dengan kegiatan keagamaan.

Hubungan sistem kepercayaan dengan struktur sosial yang tumbuh dalam masyarakat nelayan cendrung didominasi atas pandangan kolektifitas geografis dan kesadaran kebersamaan yang saling dipahami di atas makna solidaritas dan soliditas sosial secara proporsional. Konsep initentu berbeda dengan struktur sosial dalam makna stratifikasi secara umum. Konsep lapisan sosial dalam masyarakat nelayan cendrung bersifat dinamis dan praktis profesionalis. Berbeda dengan konsep lapisan atau stratifikasi kasta yang berlaku dalam Agama Hindu yang sangat tertutup.

\section{PENUTUP}

\section{Kesimpulan}

Masyarakat Nelayan Liukang Tupabbiring masih sangat kuat memegang kepercayaan-kepercayaan yang ada khususnya yang berkaitan dengan siklus kehidupan dan mata pencaharian mereka. Wujud nyata masih kuatnya kepercayaan tersebut dapat dilihat dalam keseharian mereka terutama pada kepercayaan yang berhubungan dengan kondisi alam atau cuaca, bendabenda/tempat-tempat akkarama, dan kepercayaan yang berhubungan dengan waktu (hari-hari).

Sistem kepercayaan dan struktur sosial merupakan dua hal yang berbeda. Namun eksistensinya dalam masyarakat nelayan merupakan kekuatan yang secara alami mempertahankan keutuhan/integritas sosial komunitasnya. Bahkan Terjadinya segmentasi ke dalam kelompok; papuka, papekang, pabagang, papalele, paselang, papete-pete, tukang (panrita lopi/panrita bola) menjadi nafas sebuah mobilitas sosial dan mobilitas budaya (kepercayaan) dalam masyarakat nelayan. Dari aspek pengendalian sosial, sistem kepercayaan merupakan pondasi/dasar yang paling fundamental terhadap berfungsi dan tidaknya struktur sosial memainkan perannya dalam masyarakat nelayan. Struktur sosial dipengaruhi oleh temperature penghayatan nelayan terhadap sistem kepercayaan mereka.

\section{Rekomendasi}

1. Penelitian ini memiliki keterbatasan khususnya fokus penelitian tidak menyeluruh terhadap objek penelitian. Olehnya itu disarankan kepada para akademisi untuk melakukakan pengkajian/ penelitian lebih lanjut dari sudut pandang yang berbeda guna mendapatkan informasi secara general-integral terhadap apa yang telah diteliti dalam penelitian ini.

2. Sikap selektif harus ditumbuhkembangkan oleh masyarakat nelayan dalam memahami dan melaksanakan kepercayaan-kepercayaannya oleh karena hasil penelitian ini tidak hanya menemukan faktor-faktor positif narffun juga

- secara tersirat terdapat faktor-faktor yang dapat menghambat kemajuan mereka untuk mencapai kehidupan yang lebih sejahtera.

3. Proses pembangunan pada masyarakat nelayan bukanlah persoalan mudah oleh karena disamping kesulitan keterjangkauan lokasi juga disebabkan oleh faktor-faktor non-tekhnis lainnya dapat menjadi kendala. Sistem kepercayaan dan struktur sosial harus dipandang sebagai faktor non-tekhnis yang dapat menyebabkan kegagalan pembangunan ketika kedua faktor ini diabaikan eksistensinya dalam perencanaan maupun dalam pelaksanaan pembangunan. Olehnya itu, pemahaman local wisdom oleh pemerintah dalam melakukan pembangunan pada masyarakat nelayan dengan segala keadaannya merupakan keniscayaan.

\section{Ucapan Terima Kasih}

Saya mengucapkan terima kasih kepada pengelola jurnal Al Qalam atas dimuatnya tulisan ini. Ucapan terima kasih juga saya sampaikan kepada semua informan dalam penelitian ini, karena tanpa informasi dari mereka tulisan ini tidak ada artinya. Selain itu, ucapan terima kasih kepada Dekari dan rekan-rekan dosen pada Fakultas Ekonomi dan Ilmu Sosial Universitas Negeri Makassar atas kebersamaannya selama ini, semoga kerjasama dan kebersamaan selama itu dapat tetap terjaga. 


\section{Ibrahim}

\section{AFTAR PUSTAKA}

Fortune, R.F. The Sorcerers ofDobu. London: Routledge and Sons.

Kahmad, Dadang. 2000. Sosiologi Agama. Bandung: .Rosda Karya.

Kluckhohn, C, 1944. Nahavo Witchcraf Cambridge, Massachusetts: Peabody Muesum

Koentjaraningrat. 1987. Kebudayaan Mentalitas dan Pembangunan. Jakarta: Gramedia,

Koentjaraningrat. 1987. Sejarah Antropologi I. Jakarta: Pn. UI Press.

Koentjaraningrat. 1987. Kebudayaan Mentalitas dan Pembangunan. Jakarta: Gramedia.

Marx,K. 1964. Selected Writing in sociology and Social Philosopy. New York: McGraw-Hill.

Parsons, Talcott. 1971. The System of Modem Societies. Englewood Cliffs, N.J: Prentice-Hall.
Robertson, Roland. 1992. Globalization, Politics and Religion. "The Changing Face of Religion". Newbury Park, Calif: Sage.

Robertson, Roland. 1993. Agama: Dalam Analisis Dan Interpretasi Sosiologis. Jakarta: .Pn. Rajawali Pers.

Soekanto, Soerjono, 1982. Teori Sosiologi Tentang Pribadi Dalam Masyarakat. Jakarta: Ghalia Indonesia.

Soekanto, Soerjono, J9S3.Pribadi dan Masyarakat. Bandung: Alumni.

Soekanto, Soerjono, 1987. Pengendalian Sosial. Jakarta: Rajawali.

Taylor. 1971. The Primitif Culture, Englewood Cliffs, N.J: PrenticeHall.

Turner, V.W. 1969. The Ritual Process. Chicago; Aldhine Publishing

Weber, Max, 1958.. The Protestant Ethic and The Spirit of Capitalism. New York. Scribners.

1962. TAe Sociology of Religion. Boston: Beacon Press. 